\title{
Introduction to Tractate Ta`aniot
}

As the title of the Tractate indicates, several kinds of fast days are discussed. The first topic is that of fast days in times of draught; therefore the Tractate starts with an extended discussion of prayers for rain in the rainy season. If the rains did not start come December, the rabbinic authorities are empowered to decree a series of fast days, if necessary of increasing severity. These fast days always are consecutive Monday-Thursday-Monday. On these special fast days the extended service is held in a public square, not in the synagogue; its details (together with general information on prayer and its efficacy) are given in Chapter 2. As an appendix to the description of the service in the times of the Mishnah, the service on the Temple Mount in the times of the Temple and the role of the participating delegations of priests and people is described, as also is the status of the Pharisaic (pre-rabbinic) "Scroll of Fasts" (i. e., a list of minor holidays on which fasting is forbidden). Chapter 3 enumerates calamities as consequence of which local fast days are organized. The song designated as hymn of thanks for Divine help in answer of any fast day is the "Great Hallel", Pss. 135-136. Chapter 4 takes up from Chapter 2 the topic the role of fasting priests and representatives of the public in the Temple prayer service, a feature of Pharisaic rules of the Temple service, removed from the sacrificial acts based on the Pentateuch but whose origins can be found in Chronicles. Halakhah 1 contains a lengthy section copied from Berakhot of which only the first paragraph is relevant to the topic of this Tractate. In connection with a discussion of biblically determined days on which fasts are forbidden there is mention of specific minor holidays of donations of wood to the Temple for which prophetic sanction is claimed. Of all the fast days of the current Jewish year only the $17^{\text {th }}$ of Tammuz and the $9^{\text {th }}$ of $\mathrm{Av}$ are mentioned. In the lengthy aggadic treatment of the destruction of the Temple and of Betar, there is a text which in the scribe's version asserts that the Messiah always will have to come in the future, whereas the Venice editor's text asserts that sometime in the future the Messiah will have come ${ }^{1}$.

1. An echo of the original text may be found in the Medieval text Zohar (II,8a) which 
Halakhah 2 also contains a note characterizing the Masoretic Text of the Bible of talmudic times as a scholarly edition. In order to end the Tractate on a happy note, the final Mishnah celebrates the evening following the Day of Atonement and the 15th of Av which were dedicated to match-making activities.

describes the permanent place of the Messiah, "bird's nest", in Paradise. 